\title{
The influence of a single and double biotinylation of xanthohumol on its anticancer activity*
}

\author{
Monika Stompor ${ }^{1 凶}$, Marta Świtalska² and Joanna Wietrzyk ${ }^{2}$ \\ IInstitute of Medical Sciences, University of Rzeszów, Rzeszów, Poland; ${ }^{2 H i r s z f e l d ~ I n s t i t u t e ~ o f ~ I m m u n o l o g y ~ a n d ~ E x p e r i m e n t a l ~ T h e r a p y, ~ P o l i s h ~}$ \\ Academy of Sciences, Department of Experimental Oncology, Wrocław, Poland
}

Two biotinylated derivatives of xanthohumol (1), the main hop chalcone, were prepared by one-step synthesis via esterification using biotin and coupling reagents: 1-ethyl-3-(3-dimethylaminopropyl)carbodiimide hydrochloride (EDCXHCl) and 4-dimethylaminopyridine (DMAP). The products were characterized spectroscopically and their antiproliferative activity toward the MCF-7, MCF-10A, HepG2, MDA-MB-231, 4T1 and Balb/3T3 cell lines was assessed using the SRB assay. The highest antiproliferative activity was observed in human (MCF-7) and murine (4T1) breast cancer cell lines $\left(\right.$ IC $_{50}$ values $<9$ $\mu \mathrm{M})$ for all three tested compounds. The biotinylated derivatives showed slightly higher antiproliferative activity towards all types of tested breast cancer cells, than unmodified xanthohumol (1). The double biotinylated xanthohumol (3) proved to be the most effective in inhibiting cell growth, with $\mathrm{IC}_{50}$ values equal to $5.35 \pm 1.5$ $\mu \mathrm{M}$ for $4 \mathrm{~T} 1$ and $8.03 \pm 0.53 \mu \mathrm{M}$ for MCF-7 cell lines. It also had the biggest effect in liver cancer cells HepG2 with $I C_{50}=17.37 \pm 5.1 \mu \mathrm{M}$, while the $I C_{50}$ values for 1 and 2 were $21.5 \pm 2.7$ and $22.1 \pm 3.9 \mu \mathrm{M}$, respectively. 4-O-biotinylxanthohumol (2) was the second most efficient growth inhibitor, particularly in MCF-7 $\left(I_{50}=6.19 \pm 1.7\right.$ $\mu \mathrm{M})$ and $4 \mathrm{~T} 1\left(\mathrm{IC}_{50}=6.64 \pm 0.4 \mu \mathrm{M}\right)$ cell lines. Our preliminary study on biotinylated xanthohumol (1) has shown that biotinylation can be an effective method for the production of active biomolecules and study in this area should be continued to extend their applications.

Key words: xanthohumol, biotin, biotin conjugates, anticancer activity

Received: 01 October, 2019; revised: 18 October, 2019; accepted: 08 November, 2019; available on-line: 10 December, 2019

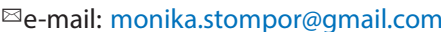

*Acknowledgements of Financial Supoort:

The costs of the article published as a part of the 44th FEBS Congress Kraków 2019 - From molecules to living systems block are financed by the Ministry of Science and Higher Education of the Republic of Poland (Contract 805/P-DUN/2019).

This study was financed by grant No. 2017/01/X/NZ9/00161 assigned by the National Science Centre, Poland, to M. Stompor.

Abbreviations: 4-dimethylaminopyridine (DMAP); 1,1-diphenyl2-picrylhydrazyl radical (DPPH); N,N-dimethylformamide (DMF); dimethyl sulfoxide (DMSO); 1-ethyl-3-(3-dimethylaminopropyl)carbodiimide hydrochloride (EDCXHCl); nuclear magnetic resonance (NMR); PBS, phosphate buffered saline; SRB sulphorhodamine $B_{i}$ TLC, thin layer chromatography; TMS, tetramethylsilane.

\section{INTRODUCTION}

Compounds of natural origin, including plant polyphenols and vitamins, are part of our daily diet. They are found in leaves, flowers, fruits, seeds, roots and bark of plants. Flavonoids have received a great deal of attention recently, due to their valuable medicinal properties (PerezVizcaino et al., 2018). The vitamins, which are also present in plants, have been shown to play an important role in many processes involved in rapid cell division in a large number of highly aggressive tumors (Halabi et al., 2018; Ferrer-Mayorga et al., 2019). As a result, such tumors often upregulate the processes involved in the uptake of several of these vitamins, namely specifically folate, vitamin $\mathrm{B}_{12}$, and biotin (vitamin H) (Russel-Jones et al., 2011). Therefore, these vitamins, and biotin in particular, have an immense potential to be used as imaging markers and targeting moieties for the delivery of cytotoxic agents to a wide variety of tumors (Maiti et al., 2018). There is also an enormous potential to use biotin in combination with folate for dual targeting for tumor cells (Luo et al., 2017). Because in some types of cancer cells biotin is found in higher concentrations than in normal cells, the addition of a biotin group to an anticancer agent may result in better delivery and selectivity for cancer cells (Kam et al., 1993; Wang et al., 2011; Tripodo et al., 2014; Soural et al., 2015; Hou et al., 2017).

Xanthohumol (1), one of the chalcone constituents of Humulus lupulus L., Sophora flavescens L., Medicago sativa L. and beer, has been reported to have a broad spectrum of biological activity, including anti-inflammatory, antioxidant, antibacterial and antidiabetic (Zhang et al., 2009; Legette et al., 2013; Fu et al., 2016; Stompor et al., 2016; Venturelli et al., 2016). Due to its strong antioxidant properties, xanthohumol is also a promising chemopreventive agent (Sun et al., 2018). Numerous in vitro studies have shown that this flavonoid inhibited cell proliferation and induced programmed cell death in many cancer cell lines, including breast, ovarian, lung, hepatic, oral, colon, cervical, prostate and leukemia ones (Guo et al., 2018; Jiang et al., 2018). Recent studies revealed that $\mathbf{1}$ has also the ability to sensitize MCF-7/ADR cells to doxorubicin, which increases cytotoxic effect of this chemotherapy drug (Liu et al., 2017). The mechanism of anticancer activity of xanthohumol described most often involves its ability to suppress cell proliferation and induce programmed cell death in cancerous cells (Min et al., 2017; Walden et al., 2017). Xanthohumol (1) and its structural analogues are also inhibitors of many enzymes, such as cyclooxygenase and lipoxygenase, which can be involved in formation of reactive oxygen species. These polyphenols of multiple functionalities can act as inhibitors of many enzymes in a mechanism of chelation through their hydroxyl groups, where they target metal ions coordinated by the enzymes (Seliger et al., 2018). Xanthohumol derivatives-enriched diet could ameliorate diabetic-associated metabolic disturbances by regulating glucose and lipid pathways (Miranda et al., 2018). Both xanthohumol (1) and its derivative 8-prenylnaringenin treatments prevented body weight gain, decreased 
triglyceride and cholesterol levels and improved insulin sensitivity (Miranda et al., 2018; Costa et al., 2017). Recent study demonstrated that daily intake of xanthohumol may significantly improve HDL function, leading to protection against atherosclerosis (Hirata et al., 2017).

However, some drawbacks such as low water-solubility of flavonoid aglycones, together with their short time of residence in the intestine and their poor absorption do not allow to experience full therapeutic effects of flavonoids through their consumption. Therefore, many researchers have devoted to modifying flavonoid structures to obtain novel derivatives with high efficiency, low toxicity and minimal side effects. Undoubtedly, there is a need for innovative, molecularly targeted therapeutic approaches for cancer treatment. Currently, there are only a few reports on the synthesis of xanthohumol (1) derivatives and their biological activity (Nuti et al., 2017; Stompor et al., 2016; Vogel et al., 2010). There are also no examples of synthesis of biologically active derivatives of prenylflavonoids conjugated with biotin. To date, there are also no reports on chemical synthesis of biotinylated xanthohumol. The comparison of antiproliferative activity of xanthohumol and its biotinylated derivatives against cancer cell lines of various origin is also lacking. Considering the valuable properties of hop flavonoids, the aim of this study was to obtain the new biotinylated derivatives of xanthohumol and determine their antiproliferative activity.

\section{MATERIALS AND METHODS}

General procedures. Xanthohumol (1) (3'-(3,3-dimethyl allyl)-2',4',4-trihydroxy-6'-methoxychalcone) was isolated from spent hops obtained from the New Chemical Syntheses Institute in Puławy, Poland. Specifically, the material used for xanthohumol isolation was the byproduct of the hops industrial extraction with supercritical $\mathrm{CO}_{2}$. Gradient grade purity methanol was purchased from Merck (Darmstadt, Germany). All other reagents, unless otherwise specified, were purchased from Sigma Aldrich (St. Louis, MO, USA) and were of analytical grade. Analytical thin-layer chromatography was carried out using silica gel $60 \mathrm{~F}_{254}$ plates (Merck) with chloroform: methanol $(96: 4 \mathrm{v} / \mathrm{v})$ as the developing solvent. A solution of $10 \mathrm{~g} \mathrm{Ce}\left(\mathrm{SO}_{4}\right)_{2}$ and $20 \mathrm{~g}$ phosphomolybdic acid in $1 \mathrm{~L}$ of $10 \% \mathrm{H}_{2} \mathrm{SO}_{4}$, was used for visualization of the compounds. Preparative column chromatography was performed using silica gel (Kieselgel 60, 230-400 mesh; Merck). NMR spectra were recorded with a Bruker $500 \mathrm{MHz}$ Ultra Shield TM Plus instrument with DMSO- $d_{6}$ as solvent and TMS as an internal standard. Highresolution mass spectra (HR-ESI-MS) were measured in methanol with a Bruker apex ultra FT-ICR instrument (Bruker, Billerica, MA, USA).

The purity of synthesized products was monitored with HPLC using an Ultimate 3000 DIONEX chromatograph equipped with an LGP-3400 RS dual-pump fluid control module, a TCC-3100 thermostatted column compartment, a WPS-3000 autosampler, and Diode Array Detector DAD-3000 RS (Sunnyvale, CA, USA). The system was controlled with and data acquisition was carried out using the Chromeleon 6.80 software (Dionex Corporation). HPLC analysis was carried out using a reverse phase C18 column (ACE 5 C18, $5 \mu \mathrm{m}, 100 \AA$, $4.6 \times 250 \mathrm{~mm}$ ) connected to a guard column (ACE 5 C18) (Advanced Chromatography Technologies LTD, Scotland). The mobile phase consisted of two components: $\mathrm{A}-1 \% \mathrm{HCOOH}$ in $\mathrm{H}_{2} \mathrm{O}$ and $\mathrm{B}-1 \% \mathrm{HCOOH}$ in $\mathrm{MeCN}$. The flow rate was set at $1 \mathrm{~mL} / \mathrm{min}$ and the gradient elution was applied with the following settings: $0-1 \mathrm{~min}, 50 \% \mathrm{~B}, 1-16 \mathrm{~min} 50-100 \% \mathrm{~B}, 16-21$ min $100 \% \mathrm{~B}, 21-23 \mathrm{~min} 100-50 \% \mathrm{~B}, 23-28 \mathrm{~min} 50 \%$ B. The total time of analysis was $28 \mathrm{~min}$. The samples' temperature was fixed at $12{ }^{\circ} \mathrm{C}$, the column temperature was fixed at $28^{\circ} \mathrm{C}$, and the injection volume was $10 \mu \mathrm{L}$. The content of 1-3 was detected at $368 \mathrm{~nm}$.

Chemistry. EDC $\times \mathrm{HCl}(230 \mathrm{mg}, 1.2 \mathrm{mmol})$ and DMAP (74 mg, $0.6 \mathrm{mmol}$ ) were added to a mixture of xanthohumol (1) (100 mg, $0.28 \mathrm{mmol})$ and biotin (276 $\mathrm{mg}, 1.13 \mathrm{mmol})$ in $\mathrm{DMF}(10 \mathrm{ml})$. The reaction mixture was stirred at $58^{\circ} \mathrm{C}$ for $24 \mathrm{~h}$. The crude products were directly purified by flash chromatography and characterized using spectroscopic methods.

4-O-biotinylxanthohumol (2). (22 $\mathrm{mg}, 13 \%)$ as a yellow solid; ${ }^{1} \mathrm{H}$ NMR (500 MHz, DMSO_d $) \delta$ (ppm): $14.46(1 \mathrm{H}, \mathrm{s}, 6$ ' $-\mathrm{OH}), 10.60\left(1 \mathrm{H}, \mathrm{s}, 4{ }^{\prime}-\mathrm{OH}\right), 7.88(1 \mathrm{H}$, $\mathrm{d}, J=15.6 \mathrm{~Hz}, \mathrm{H}-\alpha), 7.77$ (2H, d, $J=8.4 \mathrm{~Hz}, \mathrm{H}-2, \mathrm{H}-6)$, $7.69(1 \mathrm{H}, \mathrm{d}, J=15.6 \mathrm{~Hz}, \mathrm{H}-\beta), 7.21(2 \mathrm{H}, \mathrm{d}, J=8.4 \mathrm{~Hz}$, H-3, H-5), 6.46 (1H, s NH-18 or NH-17), $6.37(1 \mathrm{H}, \mathrm{s}$, NH-17 or NH-18), 6.07 (1H, s, H-3'), 5.14 (1H, t, J=6.0 Hz, H-2"), 4.33-4.31 (1H, m, H-15), 4.17-4.15 (1H, m, $\mathrm{H}-16), 3.86\left(3 \mathrm{H}, \mathrm{s},-\mathrm{OCH}_{3}\right), 3.16-3.13$ (3H, m, H-1" and $\mathrm{H}-12), 2.84(1 \mathrm{H}, \mathrm{dd}, J=12.4 \mathrm{~Hz}, J=5.0 \mathrm{~Hz}, \mathrm{H}-14)$, 2.63-2.58 (4H, m, H-8 and H-11), 1.77-1.65 (3H, m, H-9 and H-11), 1.70 (3H, s, H-5”), 1.61 (3H, s, H-4”), 1.57-1.37 (3H, m, H-11' and H-10). HRMS (ESI) $\mathrm{m} / \mathrm{r}$ : calculated. for $\left(\mathrm{C}_{31} \mathrm{H}_{36} \mathrm{~N}_{2} \mathrm{O}_{7} \mathrm{~S}+\mathrm{H}\right)^{+}=581.2316$; found $(\mathrm{M}+\mathrm{H})^{+}=581.2321$. UV $(\mathrm{MeOH}) \lambda_{\max }: 349.4 \mathrm{~nm}$.

4,4'-di-O-biotinylxanthohumol (3). (67 mg, 29\%) as a yellow solid; ${ }^{1} \mathrm{H}$ NMR (500 MHz, DMSO_d) $\delta$ (ppm): $13.11(1 \mathrm{H}, \mathrm{s}, 6$ 6'-OH), $7.82(2 \mathrm{H}, \mathrm{d}, J=8.7 \mathrm{~Hz}, \mathrm{H}-2, \mathrm{H}-6)$, $7.76(1 \mathrm{H}, \mathrm{d}, J=15.7 \mathrm{~Hz}, \mathrm{H}-\alpha), 7.72(1 \mathrm{H}, \mathrm{d}, J=15.7 \mathrm{~Hz}$, $\mathrm{H}-\beta), 7.22(2 \mathrm{H}, \mathrm{d}, J=8.7 \mathrm{~Hz}, \mathrm{H}-3, \mathrm{H}-5), 6.46$ (2H, s, $2 \times \mathrm{NH}-18$ or $2 \times \mathrm{NH}-17), 6.45\left(1 \mathrm{H}, \mathrm{s}, \mathrm{H}-3^{\prime}\right), 6.37(2 \mathrm{H}, \mathrm{s}$, $2 \times \mathrm{NH}-17$ or $2 \times \mathrm{NH}-18), 5.03(1 \mathrm{H}, \mathrm{t}, J=6.0 \mathrm{~Hz}, \mathrm{H}-2$ '”, 4.33-4.31 (2H, m, 2×H-15), 4.17-4.15 (2H, m, $2 \times \mathrm{H}-$ 16), $3.87\left(3 \mathrm{H}, \mathrm{s},-\mathrm{OCH}_{3}\right), 3.17-3.12(4 \mathrm{H}, \mathrm{m}, 2 \times \mathrm{H}-12$ and H-1"), 2.84 (2H, dd, J=12.5 Hz, J=4.8 Hz, 2×H-14), $2.62(4 \mathrm{H}, \mathrm{t}, J=7.5 \mathrm{~Hz}, 2 \times \mathrm{H}-8), 2.59(2 \mathrm{H}, 2 \times \mathrm{d}, J=12.5$ $\left.\mathrm{Hz}, \mathrm{H}-14^{\prime}\right), 1.77-1.64(6 \mathrm{H}, \mathrm{m}, 2 \times \mathrm{H}-9$ and $2 \times \mathrm{H}-11)$, 1.69 (3H, s, H-5"), 1.62 (3H, s, H-4"), 1.57-1.37 (6H, $\mathrm{m}, 2 \times \mathrm{H}-11$ ' and $2 \times \mathrm{H}-10) .{ }^{13} \mathrm{C}$ NMR $(125 \mathrm{MHz}, \mathrm{DM}-$ $\left.\mathrm{SO}-\mathrm{d}_{6}\right) \delta(\mathrm{ppm}): 193.6,171.6,171.0,162.7,161.7,159.0$, $154.3,152.2,142.1,132.3,131.1,129.9,127.4,122.5$, $121.7,114.4,110.1,97.9,61.0,59.2,56.5,55.3,40.4$, $33.3,33.2,28.02,27.98,27.89,25.4,24.31,24.29,22.0$, 17.7. HRMS (ESI) $\mathrm{m} / \approx$ : calculated for $\left(\mathrm{C}_{41} \mathrm{H}_{50} \mathrm{~N}_{4} \mathrm{O}_{9} \mathrm{~S}_{2}+\right.$ $\mathrm{H})^{+}=807.3091$; found $(\mathrm{M}+\mathrm{H})^{+}=807.3084$. UV $(\mathrm{MeOH})$ $\lambda_{\mathrm{max}}: 335.1 \mathrm{~nm}$.

Cell culture and sulphorhodamine (SRB) assay. The biological studies were performed in vitro using biotin receptor-positive human cancer cell lines: MCF7 (breast cancer), MDA-MB-231 (breast cancer), and HepG2 (liver cancer), in comparison to human normal breast cells (MCF-10A), murine biotin receptor-positive mammary gland cancer (4T1), and murine fibroblasts (BALB/3T3). The cell lines were obtained from the American Type Culture Collection (Rockville, Maryland, U.S.A.) or from the European Collection of Authenticated Cell Cultures (MCF-7 cell line; ECACC, Salisbury, $\mathrm{UK})$. The cell lines have been maintained in the Institute of Immunology and Experimental Therapy, Wroclaw, Poland.

MDA-MB-231 and 4T1 cells were cultured in RPMI1640 medium (IIET, Wroclaw, Poland), supplemented with $10 \%$ fetal bovine serum, $2 \mathrm{mM}$ L-glutamine, $1.0 \mathrm{mM}$ sodium pyruvate (4T1), and $4.5 \mathrm{~g} / \mathrm{L}$ glucose 
(4T1) (all from Sigma-Aldrich, Germany). MCF-7 cells were cultured in Eagle's medium (IIET, Wroclaw, Poland), supplemented with $10 \%$ fetal bovine serum, $1 \%$ MEM non-essential amino acid solution, $0.8 \mathrm{mg} / \mathrm{L}$ insulin and $2 \mathrm{mM}$ L-glutamine (all from Sigma-Aldrich, Germany). MCF-10A cells were cultured in the F-12 nutrient mixture (Gibco, Scotland, UK), supplemented with 5\% horse serum (Gibco, Scotland, UK), $10 \mu \mathrm{g} / \mathrm{mL}$ cholera toxin (Vibrio cholerae), $10 \mu \mathrm{g} / \mathrm{mL}$ hydrocortisone and 20 $\mathrm{ng} / \mathrm{mL}$ epidermal growth factor human (hEGF) (all from Sigma-Aldrich, Germany). HepG2 and BALB/3T3 cells were cultured in Dulbecco medium (Gibco, Scotland), supplemented with $10 \%$ fetal bovine serum, and $2 \mathrm{mM}$ L-glutamine (all from Sigma-Aldrich Germany). All culture media were supplemented with penicillin $(100$ units $/ \mathrm{mL}$; Polfa Tarchomin S.A., Poland) and streptomycin (100 $\mu \mathrm{g} /$ $\mathrm{mL}$; Sigma-Aldrich, Germany). All cell lines were grown at $37^{\circ} \mathrm{C}$ in a $5 \% \mathrm{CO}_{2}$ humidified atmosphere.

The tested compounds were dissolved in DMSO to achieve the concentration of $50 \mathrm{mM}$, and subsequently diluted in the culture medium to reach the required concentrations (ranging from $0.4 \mu \mathrm{M}$ to $250 \mu \mathrm{M}$ ). 24 hours before adding the tested compounds, the cells were seeded in 96-well plates (Sarstedt, Germany) at a density of $1 \times 10^{4}$ cells per well (4T1 cells were placed at a density of $0.7 \times 10^{3}$ cells per well) in $100 \mu \mathrm{L}$ of culture medium. SRB assay was performed 72 hours after the cells exposure to varying concentrations of the tested agents for the MCF-7, MCF-10A, 4T1, BALB/3T3, HepG2 and MDA-MB-231 cell lines. SRB cytotoxicity assay is based on the ability of sulphorhodamine B to bind electrostatically to proteins in living, but not dead, cells (the process is $\mathrm{pH}$ dependent). Therefore, it can be used to determine the density of living cells based on their protein content. The test was carried out as described before (Sidoryk et al., 2014).

The results were presented as $\mathrm{IC}_{50}$ (inhibitory concentration 50), defined as the concentration of tested agent that inhibits cell proliferation by $50 \%$. The $\mathrm{IC}_{50}$ values were calculated for each experiment separately; Table 1 shows the $\mathrm{IC}_{50}$ mean values $\pm \mathrm{S}$.D. In a single experiment, each concentration of each compound was tested in triplicate. The number of experiments varied from 3 to 5 times.

Statistical analysis. The statistical analysis was performed using Statsoft Statistica version 10. All datasets were analyzed using $t$-test. The $p$-values lower than 0.05 were considered statistically significant.

\section{RESULTS AND DISCUSION}

Clinical use of anticancer drugs is limited by their dose-dependent side effects. A smart way to deliver bioactive compounds with high antioxidant activity, for a safe and effective way to treatment life-style diseases, including cancers, could be food intervention with the use of plants. Due to the synergistic action of food ingredients such as flavonoids and cytostatic agents, it may be possible to reduce the drug dose while providing the same therapeutic effect. It could be a way to reduce harmful side effects of chemotherapeutics with no loss of treatment efficiency, because plant antioxidants can contribute to strengthening of the antioxidant barrier and stabilize DNA in the normal cells, which is highly beneficial to chemotherapy. The biological activity of flavonoids is determined by their chemical structures and their physicochemical properties, such as lipophilicity and water solubility. Our previous reports suggest that prenylation increases bioavailability and bioaccumulation of the hop flavonoid 8-prenylnaringenin and therefore may be a promising tool to apply the biological functions of hop compounds for medical use (Stompor et al., 2017). Chemical covalent modification of flavonoids is a way to modify the hydrophobic nature of these compounds and improve their solubility in water (Vogel et al., 2008; Zhang et al., 2015). Some publications indicate a higher bioavailability of flavonoid glucosides compared to the free aglycones, which may also be the way to improve their anticancer potential. However, xanthohumol glycosides obtained through microbial synthesis had lower cytotoxic activity than xanthohumol in breast (MCF-7) and prostate (PC3) cancer cell lines. A replacement of the chalcone with flavanone skeleton resulted in a significant decrease in anti-proliferative activity in breast (MCF-7), prostate (PC-3) and colon cancer (HT-29) cell lines (Tronina et al., 2013).

To answer the question whether the conjugation of two biologically important compounds would affect therapeutic activity of the obtained derivatives, possibly increasing the pro-health application of flavonoids to an industrial scale, we prepared two bifunctional molecules containing a covalently bound biotin as a vitamin fragment, differently taking into account the change in its distribution positioned in the molecule. We introduced a vitamin fragment in C-4 position and simultaneously in positions C-4 and C-4' in xanthohumol, a naturally occurring prenylated chalcone. Our aim was to obtain compounds with increased therapeutic activity resulting from the presence of isoprenyl substituent and to determine the effect of the position of the vitamin moiety in the flavonoid molecule on in vitro antiproliferation activity. The resulting xanthohumol derivatives containing either one or two ester coupled biotin molecules were further used to compare their anticancer and antioxidant activity in reference to unmodified xanthohumol.

Table 1. Antiproliferative activity of biotinylated xanthohumols.

\begin{tabular}{|c|c|c|c|c|c|c|}
\hline \multirow[t]{2}{*}{ Compounds } & \multicolumn{6}{|l|}{$\begin{array}{l}\text { Cell line } \\
\mathrm{IC}_{50}(\mu \mathrm{M})\end{array}$} \\
\hline & MCF-7 & MDA-MB-231 & HepG2 & MCF-10A & $4 \mathrm{~T} 1$ & Balb/3T3 \\
\hline 1 & $8.8 \pm 1.16$ & $18.9 \pm 4.6$ & $21.5 \pm 2.7$ & $21.1 \pm 4.3$ & $8.7 \pm 1.3$ & $12.6 \pm 8.8$ \\
\hline 2 & $6.19 \pm 1.7$ & $18.6 \pm 1.2$ & $22.1 \pm 3.9$ & $19.5 \pm 3.1$ & $6.64 \pm 0.4$ & $12.3 \pm 9.0$ \\
\hline 3 & $8.03 \pm 0.53$ & $16.9 \pm 1.6$ & $17.37 \pm 5.1$ & $16.8 \pm 2.5$ & $5.35 \pm 1.5$ & $16.6 \pm 4.0$ \\
\hline biotin & $14 \% *$ & $0 \% *$ & $0 \%{ }^{*}$ & $6.2 \%^{*}$ & $0 \%{ }^{*}$ & $0 \%{ }^{*}$ \\
\hline cisplatin & $26.7 \pm 1.7$ & $16.3 \pm 2.3$ & $5.7 \pm 1.0$ & $10.7 \pm 4.0$ & $1.0 \pm 0.17$ & $14.0 \pm 3.7$ \\
\hline
\end{tabular}

IC50, compound concentration leading to $50 \%$ inhibition of cell proliferation. Data are presented as mean \pm S.D. of 3-5 independent experiments. ${ }^{*}$ Inhibition of cell proliferation (\%) of compound at concentration of $250 \mu \mathrm{M}$ 


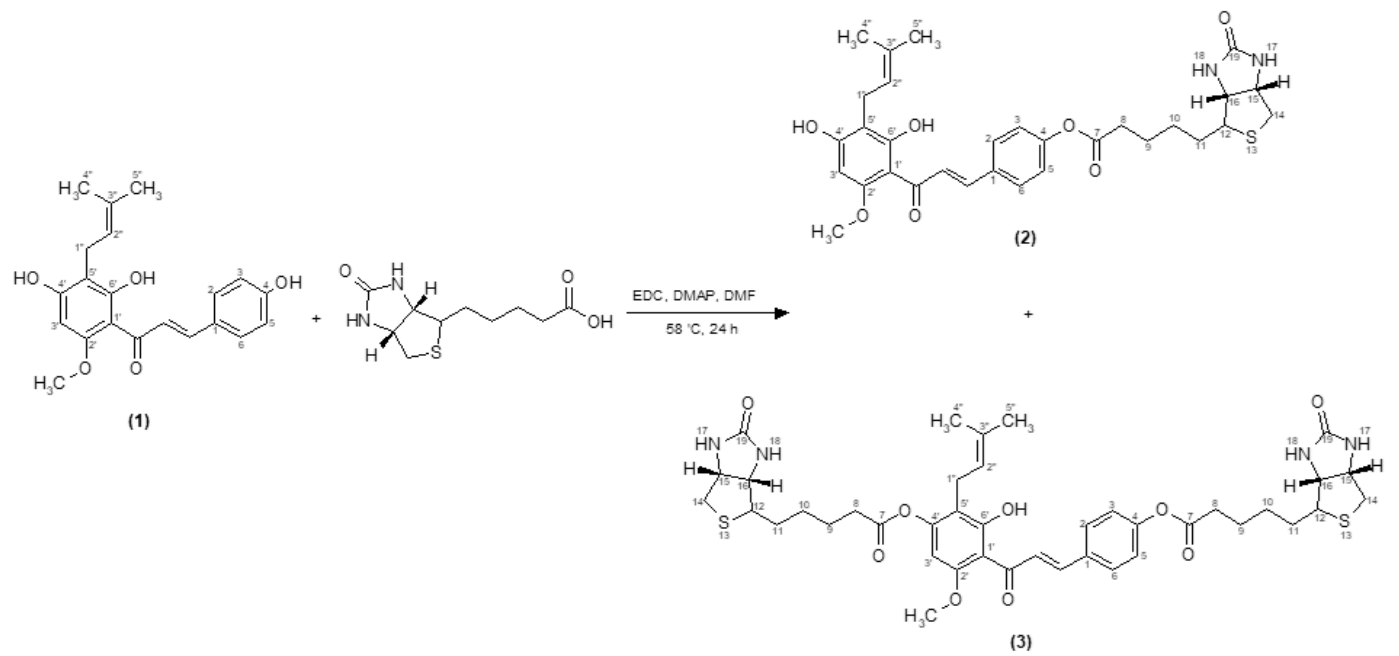

Scheme 1. Biotinylation of xanthohumol (1).

The synthesis of biotinylated derivatives of xanthohumol began with the isolation of xanthohumol from spent hops by acetone extraction. The crude xanthohumol was purified using column chromatography followed by recrystallization from dichloromethane. Treatment of xanthohumol with biotin in DMF at room temperature produced new esters (from now on, referred to as 2 and 3), which were purified by column chromatography, to obtain the pure products accounting for $13 \%$ and $29 \%$ of the yield, respectively. The synthesis of the biotinylated molecules is shown in Scheme 1. The structures of the newly synthesized compounds were determined on the basis of ${ }^{1} \mathrm{H}$ NMR (Fig. 1), ${ }^{13} \mathrm{C}$ NMR, and mass spectrometry. To verify if biotin was indeed coupled to the hydroxyl at C-4 position in xanthohumol, and not to any other hydroxyl that could be produced by transesterification, we characterized product 2 using 2D NMR spectra.

A)

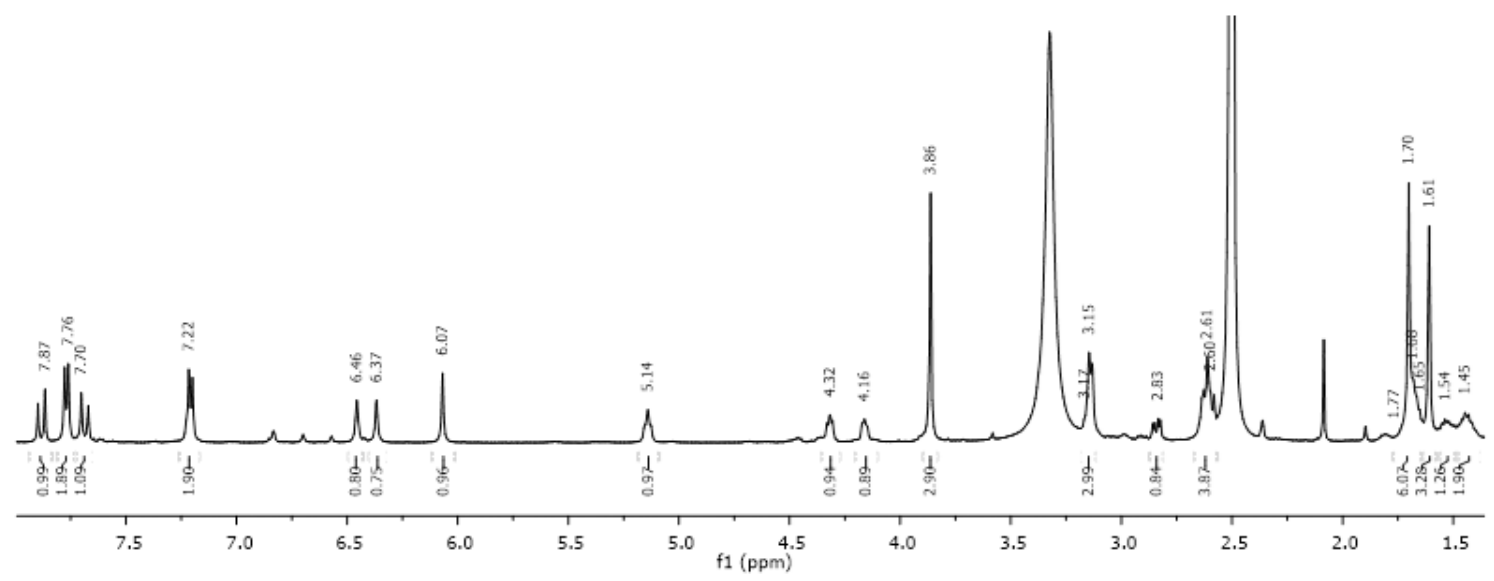

B)

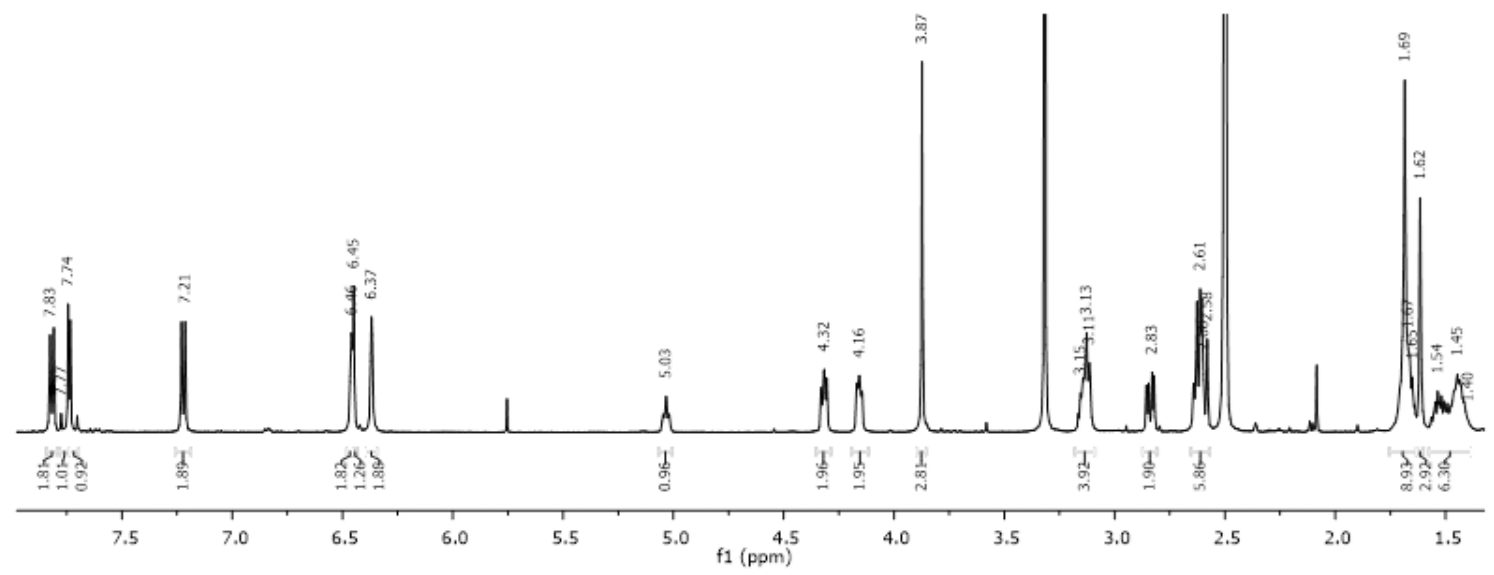

Figure 1. Fragment of ${ }^{1} \mathrm{H}$ NMR spectra of compounds 2 (A) and 3 (B) $\left(500 \mathrm{MHz}, 25^{\circ} \mathrm{C}\right.$, dmso_d $\left.d_{6}\right)$. 
In the ${ }^{1} \mathrm{H}$ NMR spectrum of 2 , the presence of two hydroxyl groups was indicated by the two one-proton singlets at 14.46 and $10.60 \mathrm{ppm}$, ascribed to the $\mathrm{OH}$ groups in the A ring at the positions C-6' and C-4', respectively. In case of $\mathbf{3}$, a signal at $13.11 \mathrm{ppm}$, attributed to a hydroxyl moiety in the C-6' position, was observed. The signals of the $\mathrm{NH}$ groups at $6.37 \mathrm{ppm}$ and 6.46 ppm were also observed.

Chemical derivatization with esters reactive to endogenous esterases is an established and effective strategy for delivering compounds to cells (Stompor et al., 2018; Tian et al., 2012). Nevertheless, esters and esterases present challenges for cell-specific small molecule delivery. Many esters show appreciable rates of enzyme-independent hydrolysis, and cellular esterases show broad substrate reactivity. In this study we found that both biotinylated xanthohumols (2 and 3 ) exhibited slightly better antiproliferative effect than the parent chalcone 1 toward all the tested breast cancer cell lines. None of the obtained compounds was significantly more active than parental xanthohumol (1) against other investigated cell lines. Therefore, it may be hypothesized that the ester group may be quickly degraded by endogenous esterase enzymes, or by another enzyme-independent pathway inside living cells.

Furthermore, the influence of flavonoids on cell function can also depend on the expression of specific receptors inside cell (Benkherouf et al., 2019), for example, estrogen receptors (Sak et al., 2014). It has been shown that hop flavonoids can increase the anti-cancer activity of other estrogen metabolites (Hessenberger et al., 2017). However, no major difference was observed in MCF-7 cells treated with xanthohumol (1) alone or co-incubated with zearalenone, a non-steroidal mycoestrogene, A trend towards an increase in the zearalenone-induced breast cancer cell proliferation (up to $72 \%$ ) was observed only for 8-prenylnaringenin, the most active natural phytoestrogen derived from hop, when added to zearalenone in amounts of 14.7 and $29.4 \mu \mathrm{M}$. (Hessenberger et al., 2017).

Up to date, the effective therapeutics for triple-negative breast cancers (TNBCs) have not been found (Jitariu et al., 2017). To better understand the influence of flavonoid compounds on the aggressive triple-negative breast cancer (TNBC), we used 4T1 and MDA-MB-231 cells that do not express the estrogen receptor (ER), progesterone receptor $(\mathrm{PgR})$ or the gene for human epidermal growth factor receptor 2 (HER-2). The nonTNBC MCF-7 cell line and non-tumorigenic human mammary MCF-10A (TNBC) epithelial cell line were used as a control. The cytotoxicity of biotin-flavonoid compounds in comparison with their non biotinylated forms was also evaluated in human liver cancer cell line HepG2. The murine cell line (Balb/3T3) was used as a non-cancer control. The human breast cancer MCF7 cell line expresses both types of estrogen receptors with a predominance of ER $\alpha$. The possible mechanism by which tumor cells proliferation can be inhibited by chemical compounds is related to their interaction with the estrogen receptor. In this research we studied the effect of xanthohumol and its biotinylated analogs also on the ER $\alpha$-negative MDA-MB 231 cell line, which is derived from a more aggressive cancer type than the $\mathrm{ER} \alpha$-positive MCF 7 cell line. Our results showed that all compounds were more active in MCF-7 cells. According to the last studies, xanthohumol inhibits cellular proliferation in MDA-MB-231 cells through an intrinsic mitochondrial-dependent pathway (Yoo et al., 2014).
The effect of xanthohumol on MCF-7 cells was described earlier by Yoshimaru and others (Yoshimaru et al., 2014). The authors reported xanthohumol $\mathrm{IC}_{50}$ value $=8.7 \mu \mathrm{M}$, which is in accordance with our observations. They also found that the oncoprotein brefeldin A inhibited guanine nucleotide-exchange protein 3 (BIG3) and suggest that the tumor suppressor prohibitin 2 (PHB2) complex plays a pivotal role in E2 signaling modulation in this ER $\alpha$-positive breast cancer. $\mathrm{XN}$ treatment effectively prevented the BIG3-PHB2 interaction, thereby releasing PHB2 to directly bind to both nuclear- and cytoplasmic ER $\alpha$. Guerreiro and others (Guerreiro et al., 2007) suggested that xanthohumol may modulate alkaline phosphatase isoenzymes in MCF-7 breast cancer cells, and that alkaline phosphatase loss was associated with increased cell proliferation. According to our results, the differences in the activity of tested compounds may be also due to the presence of $\mathrm{C}=\mathrm{O},-\mathrm{NH}-$ and $-\mathrm{S}-$ groups in biotin molecule, which have a certain degree of hydrophilicity. The N, H, and $\mathrm{S}$ atoms can also form hydrogen bonds with the components of the cell membrane, enhancing the effect of the biotinylated compounds.

Our results showed that xanthohumols esterified by biotin were also active toward normal mice fibroblasts, with the $\mathrm{IC}_{50}$ between 12.3 and $16.6 \mu \mathrm{M}$. The last molecular studies using BALB/c-4T1 breast cancer mouse model showed that xanthohumol significantly slowed down tumor growth and inhibited expression of antitumor proliferation protein $\mathrm{Ki}-67$, as well as breast cancer-specific marker - cancer antigen 15-3 (CA15-3). The analysis revealed that $\mathrm{XN}$ enhanced the secretion of perforin, granzyme $\mathrm{B}$, increased the ratio of $\mathrm{CD} 8+$ / CD25+ and deregulated selected cytokines (Th1 and Th2) (Zhang et al., 2018). In hepatocellular carcinomas HepG2 and Huh7, the inhibitory effect of xanthohumol on cell proliferation was attributed to the induction of apoptosis by decreasing cell migration and interleukin- 8 expression together with the activation of $\mathrm{NF}-x \mathrm{~B} / \mathrm{p} 53$ apoptosis signaling pathway (Dorn et al., 2010; Zhao et al., 2016). According to our results, compound 3 was slightly more active against HepG2 liver cancer cells $\left(\mathrm{IC}_{50}=17.4 \mu \mathrm{M}\right)$ than 1 and 2 , for which the $\mathrm{IC}_{50}$ doses were comparable $(\sim 22 \mu \mathrm{M})$. However, in the triple-negative breast cancer cell lines the $\mathrm{IC}_{50}$ values varied from 18.9 to $16.9 \mu \mathrm{M}$ and from 8.7 to $5.35 \mu \mathrm{M}$, for MDAMB-231 and 4T1, respectively (Table 1). These suggest that the antiproliferative activity of tested flavonoids against various cancer cell lines may be determined by their chemical structures and by their physicochemical properties, such as size of the molecules. However, molecular weights of the biotinylated compounds 2 and 3 are much higher than of the unsubstituted substrate 1. Thus, with the increased molecular weight it became more difficult for the biotinylated chalcones to get through the cell membrane, and therefore the number of biotinylated derivative molecules entering the cell may be too low. Nevertheless, the best antiproliferative activity was noted for the two biotins containing and having the highest molecular weight (about $806.98 \mathrm{~g} / \mathrm{mol}$ ) compound 3 . The second most active compound was 2 , having one biotin and $\mathrm{M}=580.69 \mathrm{~g} / \mathrm{mol}$. The molecular weight increase in modified xanthohumols (by about $226-452 \mathrm{~g} / \mathrm{mol}$ ) not only did not diminish the antiproliferative activity but seemingly enhanced it, compared to the parental xanthohumol (1).

It may be hypothesized that biotin-containing compounds would enter the biotin-positive cancer cells more efficiently than the non-tumorigenic fibroblasts 
(Balb/3T3) and pre-neoplastic mammary epithelial cells (MCF-10A), leading to oxygen reduction by flavonoid moiety and an increased ROS generation and ultimately, cell death. It can also be hypothesized that the vitamin moiety binds to biotin receptors on cancer cells with greater frequency than to noncancer cells, resulting in the preferable conjugate uptake and leading to higher inhibition of proliferation. In this context, the nonTNBC MCF-7 cells, characterized by biotin over folate receptors predominance, were more sensitive to tested compounds than the more aggressive TNBC metastatic human breast cancer cell lines, that over-express biotin receptors, but are deprived of ER and HER-2 receptors (e.g. MDA-MB-231).

The last studies suggested that xanthohumol's antitumor activity may arise from its ability to inhibit multiple target proteins in cancer cells and that it could be used in anticancer therapy (Jiang et al., 2018). Based on their diverse biological activity, hop flavonoids, e.g. isoxanthohumol, may also be the potential adjuvant agents in cancer treatment (Krajnović et al., 2016). Also, other prenylated chalcones (e.g. O-prenyl derivative of 2'-hydroxy$3,4,4^{\prime}, 5,6^{\prime}$-pentamethoxychalcone) in combination with common anticancer drug, such as paclitaxel, have been shown to further inhibit cell growth, as determined with cell viability and proliferation assays (Fonseca et al., 2016).

In summary, the results obtained in this study support the advisability of combining two groups with therapeutic activity in one molecule. This type of strategy can be a pattern for designing biologically active agents, also due to much lower probability of resistance to such constructs. The future availability of new derivatives will allow to extend this research to their biochemical mechanism of activity and the relationship between their biological activity and structure.

\section{CONCLUSION}

In summary, we have synthesized two novel low-molecular-weight compounds (2 and 3 ) using a simple ester coupling of biotin and xanthohumol (4-O-biotinylxanthohumol and 4,4'-di-O-biotinylxanthohumol, respectively), the main flavonoid of hop (Humulus lupulus). The antiproliferative activity of biotinylated derivatives of xanthohumol (compounds 2 and 3 ) was examined in selected cancer cell lines and compared to the effect of unmodified xanthohumol. Our results clearly showed that incorporation of biotin moiety into the main hop prenyl chalcone may modify its selective cytotoxic activity. The obtained results are promising, and, in our opinion, qualify the two newly synthesized compounds for further in vivo study as anticancer agents. The derivatives described here can be obtained in short, one-step synthesis and could be a useful tool to study tumor biology in living cells using a range of methods, like affinity capture, flow cytometry, confocal microscopy, spectroscopic and luminescence methods and other imaging techniques used in medicine. To our knowledge, 2 and 3 constitute the only reported biotinylated chalcone probe to have such combined characteristics. In addition, this study shows a potential benefit of utilization of the by-products of supercritical carbon dioxide extraction of hop cones, that is common in the brewing industry (spent hops). This waste material is rich in 1 , which we used as a substrate for the synthesis of 2 and its derivatives. These studies are in progress. The aim of further work is to elucidate the mechanism of cytotoxicity of the biotin-modified flavonoids.

\section{Conflict of interest}

The authors declare that they have no competing interests.

\section{REFERENCES}

Benkherouf AY, Soini SL, Stompor M, Uusi-Oukari M (2019) Positive allosteric modulation of native and recombinant $\mathrm{GABA}_{\mathrm{A}}$ receptors by hops prenylflavonoids. Eur J Pharmacol 852: 34-41. https://doi. org/10.1016/j.ejphar.2019.02.034

Costa R, Rodrigues I, Guardão L, Rocha-Rodrigues S, Silva C, Magalhães J, Ferreira-de Almeida M, Negrão R, Soares R (2017) Xanthohumol and 8-prenylnaringenin ameliorate diabetic-related metabolic dysfunctions in mice. I Nutr Biochem 45: 39-47. https://doi. org/10.1016/j.jnutbio.2017.03.006

Dorn C, Kraus B, Motyl M, Weiss TS, Gehrig M, Schölmerich J, Heilmann J, Hellerbrand C (2010) Xanthohumol, a chalcon derived from hops, inhibits hepatic inflammation and fibrosis. Mol Nutr Food Res 54: 205-2013. https://doi.org/10.1002/mnfr.200900314

Ferrer-Mayorga G, Larriba MJ, Crespo P, Muñoz A (2019) Mechanisms of action of vitamin D in colon cancer. I Steroid Biochem Mol Biol 185: 1-6. https://doi.org/10.1016/j.jsbmb.2018.07.002

Fonseca J, Marques S, Silva, PMA, Brandão P, Cidade H, Pinto MM, Bousbaa H (2016) Prenylated chalcone 2 acts as an antimitotic agent and enhances the chemosensitivity of tumor cells to paclitaxel. Molecules 21: 982. https://doi.org/10.3390/molecules21080982

Fu W, Chen L, Wang Z, Zhao C, Chen G, Liu X, Dai Y, Cai Y, Li C, Zhou J, Liang G (2016) Determination of the binding mode for anti-inflammatory natural products xanthohumol with myeloid differentiation protein 2. Drug Des Devel Ther 10: 455-463. https://doi. org/10.2147/DDDT.S98466

Guerreiro S, Monteiro R, Martins MJ, Calhau C, Azevedo I, Soares $\mathrm{R}$ (2007) Distinct modulation of alkaline phosphatase isoenzymes by 17 beta-estradiol and xanthohumol in breast cancer MCF-7 cells. Clin Biochem 40: 268-273. https://doi.org/10.1016/j.clinbiochem.2006.09.012

Guo D, Zhang B, Liu S, Jin M (2018) Xanthohumol induces apoptosis via caspase activation, regulation of $\mathrm{Bcl}-2$, and inhibition of PI3K/ Akt/mTOR-kinase in human gastric cancer cells. Biomed Pharmacother 106: 1300-1306. https://doi.org/10.1016/j.biopha.2018.06.166

Halabi IE, Bejjany R, Nasr R, Mukherji D, Temraz S, Nassar FJ, El Darsa H, Shamseddine A (2018) Ascorbic acid in colon cancer: from the basic to the clinical applications. Int J Mol Sci 19: 2752. https://doi.org/10.3390/ijms19092752

Hessenberger S, Botzi K, Degrassi C, Kovalsky P, Schwab C, Schatzmayr D, Schatzmayr G, Fink-Gremmels J (2017) Interactions between plant-derived oestrogenic substances and mycoestrogen zearalenone in a bioassay with MCF-7 cells. Pol J Veter Sci 20: 513-520. https://doi.org/10.1515/pjvs-2017-0062

Hirata H, Uto-Kondo H, Ogura M, Ayaori M, Shiotani K, Ota A, Tsuchiya Y, Ikewaki K (2017) Xanthohumol, a hop derived prenylated flavonoid, promotes macrophage reverse cholesterol transport. J Nutr Biochem 47: 29-34. https://doi.org/10.1016/j.jnutbio.2017.04.011

Hou X, Wei W, Fan Y, Zhang J, Zhu N, Hong H, Wang C (2017) Study on synthesis and bioactivity of biotinylated emodin. Appl Microbiol Biotechnol 101: 5259-5266. https://doi.org/10.1007/s00253017-8243-3

Jiang CH, Sun, TL, Xiang DX, Wei SS, Li WQ (2018) Anticancer activity and mechanism of xanthohumol: a prenylated flavonoid from hops (Humulus lupulus L). Front Pharmacol 22: 530. https://doi. org $/ 10.3389 /$ fphar.2018.00530

Jitariu AA, Cimpean AM, Ribatti D, Raica M (2017) Triple negative breast cancer: the kiss of death. Oncotarget 8: 46652-46662. https:// doi.org/10.18632/oncotarget.16938

Kam C, Abuelyaman AS, Li Z, Hudig D, Powers JC (1993) Biotinylated isocoumarins, new inhibitors and reagents for detection, localization, and isolation of serine proteases. Bioconjugate Chem 4: 560-567. https://doi.org/10.1021/bc00024a021

Krajnović T, Kaluderović GN, Wessjohann LA, Mijatović S, Maksimović-Ivanić D (2016) Versatile antitumor potential of isoxanthohumol: enhancement of paclitaxel activity in vivo. Pharmacol Res 105: 62-73. https://doi.org/10.1016/j.phrs.2016.01.011

Legette LL, Luna AY, Reed RL, Miranda CL, Bobe G, Proteau RR, Stevens JF (2013) Xanthohumol lowers body weight and plasma glucose in obese male Zucker fa/fa rats. Phytochemistry 91: 236-241. https://doi.org/10.1016/j.phytochem.2012.04.018

Liu M, Yin H, Qian X, Dong J, Qian Z, Miao J (2017) Xanthohumol, a prenylated chalcone from hops, inhibits the viability and stemness 
of doxorubicin-resistant MCF-7/ADR cells. Molecules 22: 36. https://doi.org/10.3390/molecules22010036

Luo W, Wen G, Yang L, Tang J, Wang J, Wang J, Zhang S, Zhang L, Ma F, Xiao L, Wang Y, Li Y (2017) Dual-targeted and pH-sensitive doxorubicin prodrug-microbubble complex with ultrasound for tumor treatment. Theranostics 7: 452-465. https://doi.org/10.7150/ thno.16677

Maiti S, Paira P (2018) Biotin conjugated organic molecules and proteins for cancer therapy: a review. Eur J Med. Chem 145: 206-223. https://doi.org/10.1016/j.ejmech.2018.01.001

Min F, Zhang L, Chen Y, Zhai L, Zhou W, Gao X, Lin C (2017) Xanthohumol inhibits proliferation in lymphoma cells by generation of reactive oxygen species and G0/G1-phase cell cycle arrest. Int J Clin Exp Med 10: 10091-10102. http://www.ijcem.com/files/ ijcem0047359.pdf

Miranda CL, Johnson LA, De Montgolfier O, Elias VD, Ullrich LS, Hay JJ, Paraiso IL, Choi J, Reed RL, Revel JS, Kioussi C, Bobe G, Iwaniec UT, Turner RT, Katzenellenbogen BS, Katzenellenbogen JA, Blakemore PR, Gombart AF, Maier CS, Raber J, Stevens JF (2018) Non-estrogenic xanthohumol derivatives mitigate insulin resistance and cognitive impairment in high-fat diet-induced obese mice. Sci Rep 8: 613. https://doi.org/10.1038/s41598-017-18992-6

Nuti E, Bassani B, Camodeca C, Rosalia L, Cantelmo A, Gallo C, Baci D, Bruno A, Orlandini E, Nencetti S, Noonan DM, Albini A, Rossello A (2017) Synthesis and antiangiogenic activity study of new hop chalcone xanthohumol analogues. Eur J Med Chem 138: 890899. https://doi.org/10.1016/j.ejmech.2017.07.024

Perez-Vizcaino F, Fraga CG (2018) Research trends in flavonoids and health. Arch Biochem Biophys 646: 107-112. https://doi.org/10.1016/j. abb.2018.03.022

Russel-Jones G, McTavish K, McEwan J (2011) Preliminary studies on the selective accumulation of vitamin-targeted polymers within tumors. J Drug Target 19: 133-139. https://doi. org/10.3109/10611861003734027

Sak K (2014) Cytotoxicity of dietary flavonoids on different human cancer types. Pharmacogn Rev 8: 122-146. https://doi. org/10.4103/0973-7847.134247

Seliger JM, Misuri, L, Maser E, Hintzpeter J (2018) The hop-derived compounds xanthohumol, isoxanthohumol and 8-prenylnaringenin are tight-binding inhibitors of human aldo-keto reductases $1 \mathrm{~B} 1$ and 1B10. J Enyyme Inbib Med Chem 33: 607-614. https://doi.org/10.108 $0 / 14756366.2018 .1437728$

Sidoryk K, Jaromin A, Edward JA, Świtalska M, Stefańska J, Cmoch P, Zagrodzka J, Szczepek W, Peczyńska-Czoch W, Wietrzyk J, Kozubek A, Zarnowski R, Andes DR, Kaczmarek E (2014) Searching for new derivatives of neocryptolepine: synthesis, antiproliferative, antimicrobial and antifungal activities. Eur J Med Chem 78: 304-313. https://doi.org/10.1016/j.ejmech.2014.03.060

Stompor M, Uram L, Podgórski R (2017) In vitro effect of 8-prenylnaringenin and naringenin on fibroblasts and glioblastoma cells-cellular accumulation and cytotoxicity. Molecules 22: 1092. https://doi. org $/ 10.3390 /$ molecules 22071092

Stompor M, Świtalska M, Wietrzyk J (2018) Synthesis and biological evaluation of acyl derivatives of hydroxyflavones as potent antiproliferative agents against drug resistance cell lines. Zeitschr Natur C 73: 87-93. https://doi.org/10.1515/znc-2017-0093

Stompor M, Zarowska B (2016) Antimicrobial activity of xanthohumol and its selected structural analogues. Molecules 21: 608. https://doi. org $/ 10.3390 /$ molecules 21050608

Soural M, Hodon J, Dickinson NJ, Sidova V, Gurska S, Dzubak P, Hajduch M, Sarek J, Urban M (2015) Preparation of conjugates of cytotoxic lupine triterpen with biotin. Bioconjug Chem 26: 2563-2570. https://doi.org/10.1021/acs.bioconjchem.5b00567

Sun Z, Zhou C, Liu F, Zhang W, Chen J, Pan Y, Ma L, Liu Q, Du Y, Yang J, Wang Q (2018) Inhibition of breast cancer cell survival by xanthohumol via modulation of the notch signaling pathway in vivo and in vitro. Oncol Lett 15: 908-916. https://doi.org/10.3892/ ol.2017.7434

Tian L, Yang Y, Wysocki LM, Arnold AC, Hu A, Ravichandran B, Sternson AM, Looger LL, Lavis LD (2012) Selective esterase-ester pair for targeting small molecules with cellular specificity. PNAS 109: 4756-4761. https://doi.org/10.1073/pnas.1111943109

Tripodo G, Mandracchia D, Collina S, Rui M, Rossi S (2014) New perspectives in cancer therapy: the biotin-antitumor molecule conjugates. Med Chem 2014, S1: 004. https://doi.org/10.4172/2161-0444. S1-004

Tronina T, Bartmańska A, Mielczarek M, Wietrzyk J, Popłoński J, Rój E, Huszcza E (2013) Antioxidant and antiproliferative activity of glycosides obtained by biotransformation of xanthohumol. Bioorg Med Chem Lett 23: 1957-1960. https://doi.org/10.1016/j. bmcl.2013.02.031

Venturelli S, Burkard M, Biendl M, Lauer UM, Frank J, Busch C (2016) Prenylated chalcones and flavonoids for the prevention and treatment of cancer. Nutrition 32: 1171-1178. https://doi.org/10.1016/j. nut.2016.03.020

Vogel S, Barbic M, Jürgenliemk G, Heilmann J (2010) Synthesis, cytotoxicity, anti-oxidative and anti-inflammatory activity of chalcones and influence of A-ring modifications on the pharmacological effect. Eur J Med Chem 45: 2206-2213. https://doi.org/10.1016/j.ejmech.2010.01.060

Vogel S, Ohmayer S, Brunner G, Heilmann J (2008) Natural and non-natural prenylated chalcones: synthesis, cytotoxicity and antioxidative activity. Bioorg Med Chem 16: 4286-4293. https://doi. org/10.1016/j.bmc.2008.02.079

Walden D, Kunnimalaiyaan S, Sokolowski K, Clark TG, Kunnimalaiyaan M (2017) Antiproliferative and apoptotic effect of xanthohumol in cholangiocarcinoma. Oncotarget 8: 88069-88078. https://doi. org/10.18632/oncotarget.21422

Wang RE, Hunt CR, Chen JW, Taylor JS (2011) Biotinylated quercetin as an intrinsic photoaffinity proteomics probe for the identification of quercetin target proteins. Bioorg Med Chem 19: 4710-4720. https://doi.org/10.1016/j.bmc.2011.07.005

Yoo YB, Park KS, Kim JB, Kang HJ, Yang JH, Lee EK, Kim HY (2014) Xanthohumol inhibits cellular proliferation in a breast cancer cell line (MDA-MB-231) through an intrinsic mitochondrialdependent pathway. Indian J Cancer 51: 518-523. https://doi. org/10.4103/0019-509X.175328

Yoshimaru T, Komatsu M, Toshiro E, Imoto M, Osada H, Miyoshi Y, Honda J, Sasa M, Katagiri T (2014) Xanthohumol suppresses oestrogen-signaling in breast cancer through the inhibition of BIG-PHB2 interactions. Sci Rep 4: 7355. https://doi.org/10.1038/ srep07355

Zhang B, Duan D, Ge C, Yao J, Liu Y, Li X, Fang J (2015) Synthesis of xanthohumol analogues and discovery of potent thioredoxin reductase inhibitor as potential anticancer agent. J Med Chem 58: 1795-1805. https://doi.org/10.1021/jm5016507

Zhang N, Liu Z, Han Q, Chen J, Lou S, Qiu J, Zhang G (2009) Inhibition of bovine viral diarrhea virus in vitro by xanthohumol: comparisons with ribavirin and interferon- $\alpha$ and implications for the development of anti-hepatitis C virus agents. Eur J Pharm Sci 38: 332-340. https://doi.org/10.1016/j.ejps.2009.08.005

Zhang W, Pan Y, Gou P, Zhou C, Ma L, Liu Q, Du Y, Yang J, Wang Q (2018) Effect of xanthohumol on Th1/Th2 balance in a breast cancer mouse model. Oncol Rep 39: 280-288. https://doi. org/10.3892/or.2017.6094

Zhao X, Jiang K, Liang B, Huang X (2016) Anticancer effect of xanthohumol induces growth inhibition and apoptosis of human liver cancer through NF- $x \mathrm{~B} / \mathrm{p} 53$-apoptosis signaling pathway. Oncol Rep 35: 669-675. https://doi.org/10.3892/or.2015.4455 